\title{
PALEOGEOGRAPHICAL IMPLICATIONS OF PENNSYLVANIAN BRACHIOPODS AND BIVALVES FROM IXTALTEPEC FORMATION, OAXACA, SOUTHEAST MEXICO.
}

QUIROZ-BARROSO, Sara A.; SOUR-TOVAR*, Francisco, Museo de Paleontología de la Facultad de Ciencias, U.N.A.M. Cd. Universitaria, México, D. F., C.P. 04510.

Several species of brachiopods and bivalves were collected in the type section of Ixtaltepec Formation. This formation crops out in Nochixtlan municipality, Oaxaca State, at lat. $17^{\circ} 33^{\prime} \mathrm{N}$ and long. $97^{\circ} 07^{\prime} \mathrm{W}$. The brachiopods species colleted are: Orbiculoidea missouriensis, Orthotetes sp., Derbyia crassa, Neochonetes granulifer, Neochonetes sp., Sinuatella sp., Echinaria semipunctata, Reticulatia huecoensis, Linoproductus echinatus, Linoproductus planiventralis, Leiorhyncus carboniferus, Composita ovata, Anthracospirifer occiduus, Neospirifer dunbari, Neospirifer sp., and Punctospirifer transversus; the bivalves found are: Nuculopsis sp., Palaeoneilo sp., Paleyoldia sp., Phestia bellistriata, Parallelodon tenuistriatus, Myalinella meeki, Septimyalina sp., Leptodesma sp., Pterinopectinella sp., Aviculopecten sp., Limipecten sp., Streblopteria sp., Euchondria sp., Schizodus sp., Permophorus spinulosa, Astartella concentrica, Edmondia ovata, and Ectogrammysia prolata.

The analysis of this fauna indicates a Pennsylvanian age (Morrowan-Desmoinesian), with reefal conditions for the calcareous beds at the base of the formation and perireefal environments for the middle-upper portion, composed of terrigenous sediments.

Species mentioned above have been reported in Pennsylvanian outcrops of North America, and there is a great similarity with faunas from the "Mid-Continent" province. These data allow to establish that, during Carboniferous times, existed some sort of geographical connection and similar climatic and paleoenvironmental conditions between the central region of the United States and southeast Mexico. In order to clearly establish paleobiogeographical relations between both regions, it is necessary to know in detail the paleontological and paleoenvironmental features of the other carboniferous-permian outcrops in Mexico, specially those ones of Tamaulipas, Hidalgo, Puebla and Guerrero states, which might give more information about transition zones. 